\title{
MENCERDASKAN ANAK BANGSA MELALUI PENDEKATAN PEMBELAJARAN PENDIDIKAN ANAK USIA DINI
}

\author{
Oleh \\ Siti Zaenab ${ }^{1}$, I Nyoman Sueca ${ }^{2}$ \\ ${ }^{1}$ Stahn Gde Puja Mataram \\ ${ }^{2}$ Dosen IHDN Denpasar \\ sita.zaenab99@gmail.com
}

\begin{abstract}
Government policy in a program with education care, and early childhood development (PAUD) as a concrete manifestation of the government's commitment is in the document "National Program for Indonesian Children (PNBAI). The important value of early childhood (early childhood) period for the growth and development ofchildren in the future, is increasingly realized by parents. This growing awareness raises an escalation of interest for quality early childhood education that can meet their expectations.

The intelligence that occurs in children, cognitive theory and psychoanalytic theory is very important in supporting children play a reference in determining the stage of child development in terms of cognitive, afktif, psikomotorik, language, and social emotional. Early childhood learning approach as the main arena in instilling knowledge of Indonesian children aged 4-5 years is done with various setrategi as a skill in mengartur appropriate learning, in order to achieve maximum results which is the hope of society.

In some rural communities, many still do not take advantage of their early childhood education opportunities, many factors affect the economy, parents, and the distance to school. During this education from tingkan PAUD to kindergarten in rural areas almost mostly built by the party suwasta in the form of the foundation. This is something that needs to get the attention of the central government to the district level.
\end{abstract}

\section{Keywords: To hatch the nation's children}

\begin{abstract}
Abstrak
Kebijakan pemerintah dalam sebuah program dengan pengasuhan pendidikan, dan pengembangan anak usia dini (PAUD) sebagai wujud nyata komitmen pemerintah adalah yang temuat dalam dokumen berupa "Program Nasional Bagi Anak Indonesia (PNBAI). Nilai penting periode anak usia dini (PAUD) bagi pertumbuhan dan perkembangan anak dimasa yang akan datang, semakin disadari oleh orang tua. Kesadaran yang terus tumbuh tersebut menimbulkan eskalasi/pertambahan minat terhadap pendidikan anak usia dini yang berkualitas yang bisa memenuhi harapan mereka.

Kecerdasan yang terjadi pada anak-anak, teori kognitif dan teori psikoanalitis sangat penting dalam menunjang main anak menjadi acuan dalam menentukan tahap perkembangan anak baik dari segi kognitif, afktif, fisikomotorik, bahasa, maupun sosial emosional. Pendekatan pembelajaran anak usia dini sebagai ajang utama dalam penanamkan pengetahuan terhadap anak Indonesia yang berumur 4-5 tahun dilakukan dengan berbagai setrategi sebagai sebuah ketrampilan dalam mengartur pembelajaran yang sesuai, agar mencapai hasil maksimal yang merupakan harapan masyarakat.

Di beberapa masyarakat daerah pedesaan masih banyak belum memanfaatkan kesempatannya untuk membeikan pendidikan usia dini terhadap anak-anak mereka, hal ini banyak faktor yang mempengaruhi misalkan, ekonomi, kesibukan orang tua maupun jarak
\end{abstract}


tempuh menuju sekolah. Selama ini pendidikan dari tingkan PAUD sampai TK di daerah pedesaan hampir sebagian besar dibangun oleh pihak suwasta dalam wujud yayasan. Hal ini merupakan hal yang perlu mendapatkan perhatian dari pemerintah pusat samapai ketingkat kota kabupaten.

\section{Kata Kunci: Mencedaskan anak bangsa}

\section{PENDAHULUAN}

Berbagai bentuk kebijakan dan kesepakan secara nasional telah mendorong pemerintah untuk menyusun berbagai program yang terkait dengan pengasuhan pendidikan, dan pengembangan anak usia dini. sebagai wujud nyata komitmen pemerintah adalah beberapa kebijakan dasar yang temuat dalam dokumen berupa "Program Nasional Bagi Anak Indonesia (PNBAI)" sampai 2015 yang isinya antara lain: (1) mewujudkan anak yang sehat, tumbuh dan berkembang secara optimal melalui pemberdayaan masyarakat, (2) peningkatan kerja sama lintas sektoral, perbaikan lingkungan, peningkatan kualitas kesehatan, peningkatan sumber daya manusia, serta pengembangan ilmu pengetahuan, (3) mewujudkan perlindungan dan partisipasi aktif anak melalui perbaikan mutu pranata sosial dan hukum, pemerataan dan perluasan jangkauan pelayanan terutama bagi anak yang berada dalam keadaan darurat dalam jaringan kerja nasional dan internasional. Sebagai wujud dari program pemerintah secara nasional untuk mencapai cita-cita bangsa yaitu menjadikan anak bangsa yang sehat dan cerdas maka penanaman pendidikan sejak dini sangat utama melalui pendidikan anak usia dini. Yang ditekankan dalam pengasuhan pendidikan adalah kebebasan yang ada pada anak melalui bermain.

Pembelajaran pada pendidikan anak usia dini lebih ditekankan pada metode bermain oleh pendidik. Menurut JJ Rousseau (dalam Afandi,dkk. 2014:100) menyatakan bahwa, bermain adalah merupakan kodrat anak dan mereka memilki kemampuan untuk memilih apa yang ingin mereka pelajari, anak bermain karena menginginkan kebebasan. Kemudian ide gagasan free play dikembangkan oleh para ahli pendidikan dengan menggunakan istilah discovery learning (pembelajaran untuk menemukan)yang pada intinya mempunyai tujuan dan maksud yang sama, dan dalam pelaksanaannya juga mengundang unsure-unsur belajar serta dalam kebebsannya bermain dengan berbagai alat, bahan dan perlengkapan yang telah tersedia. Anak-anak mencoba, salah, mencoba salah, terus diulang-ulang sampai akhirnya mereka menemukan sesuatu yang baru merekla ketahui dari kegiatan yang mereka lakukan tersebut.

Anak-anak diharapkan mendapatkan kesempatan yang cukup untuk melakukan kegiatan yang mereka pilih sendiri tanpa ada intervensi dari guru. Guru hanyan menjadi fasilitator, motivator, observator, dan evaluator. Dengan begitu anak-anak, akan dapat 
mengembangkan pengetahuan sendiri bersamaan dengan pengembangan perilaku sosial, kreativitas, kemandirian, arahan diri, konsep diri, motivasi diri dan kepercayaan diri.

Untuk mencerdasakan anak bangsa yang diawali dengan pendidikan anak usia dini merupakan awal yang akan menuju pendidikan formal, sehingga pendidikan awal sampai di perguruan tinggi tidak ada diskriminasi terhadap orang-orang yang berkelas. Pendidikan usia dini sampai kependidikan dasar merupakan pondasi yang sangat perlu memperoleh perhatian oleh kedua orang tua maupun lingkungannya. Pendidikan pada anak usia dini dimana guru lebih menekankan pada pola bermain. Anak bermain dengan menggunakan mainan yang konkrit (nyata), dengan mainan tersebut anakanak belajar bnayak hal seperti: warna warni, ukuran, bentuk, besar kecil, berat ringan, kasar halus, dan selain itu anak akan belajar mengelompokkan benda, cirri-ciri benda, dan sifat-sifat benda. Kemampuan anak untuk belajar tersebut akan terus terbangun baik saat anak anakanak bemani maupun saat mereka beresberes setelah mereka bermain.

Anak bermain untuk memperoleh sesuatu dengan cara berekplorasi atau menemukan sesuatu dan berekspirimen atau dengan pengamatan sendiri tentang dunia di sekitarnya dalam rangka membangun pengetahuan diri sendiri (self knowledge). Untuk dapat mendukung anak berekplorasi dengan mainnya guru perlu memerhatikan densitas (density) dan itensitas (intensity) main. Densitas adalah berbagai macam cara setiap jenis main (main sensorimotor), main peran, dan main pembangunan) yang disediakan untuk mendukung pengalaman anak. Adapun itensitas adalah sejumlah waktu yang dibutuhkan anak untuk pengalaman dalam tiga jenis main sepanjang hari dan sepanjang tahun, yaitu atas inisiatif anak, atas keputusan anak, dan dengan dukungan guru atau orang dewasa.

Mengapa manusia bermain, dalam beberapa teori tentang bermain yang dikemukakan oleh para ahli dari berbagai disiplin ilmu mengemukakan antara lain: (1) Teori psikoanalistis yang dikembangkan oleh Sigmund Freud dan erik erikson (dalam Zubaidah dkk. 2004:78) menyatakan bahwa bermain anak sebagai alat, yang penting bagi pelepasan emosinya serta untuk mengembangkan rasa harga diri anak, ketika anak dapat menguasai tubuhnya. (2) Teori perkembangan kognitif oleh Jean Piaget (dalan Zubaidah dkk. 2004:79) berpendapat bahwa setiap manusia mempunyai pola struktur kognitif baik itu secara fisik maupun mental yang mendasari prilaku dan aktivitas inteligensi seseorang dan berhubungan erat dengan tahap pertumbuhan anak. Dia berpendapat bahwa intelektual (kognitif) dan afektif selalu berjalan berdampinganseperti layaknya sebuah koin. Teori ini percaya bahwa, emosi dan afeksi manusia muncul dari suatu proses yang sama didalam tahapan tumbuh kembang konitif, sehingga Piaget membagi tahapan tumbuh kembang kognitif kedalam empat jjenis proses: asimilasi, akomodasi, konservasi, dan reversibility. (3) Teori dari Vigotsky lebih menekankan kepada pemusatan 
hubungan sosial sebagi hal penting yang mempengaruhi perkembangan kognitif, karena pertam-tama anak menemukan pengetahuan dalam dunia sosialnya, kemudian menjadi bagian dari kognitifnya.

Kecerdasan yang terjadi pada anak-anak, sehingga teori kognitif dan teori psikoanalitis sangat penting dalam menunjang main anak menjadi acuan dalam menentukan tahap perkembangan anak baik dari segi kognitif, afktif, fisik motorik, bahasa, maupun sosial emosional. Nilai penting periode anak usia dini (PAUD) bagi pertumbuhan dan perkembangan anak dimasa yang akan datang, semakin disadari oleh orang tua. Kesadaran yang terus tumbuh tersebut menimbulkan eskalasi/pertambahan minat terhadap pendidikan anak usia dini yang berkualitas yang bisa memenuhi harapan mereka. Eskalasi tersebut ditambah dengan perkembangan dan pengembangan metode belajar mengajar membuat PADU mulai berbenah diri. Sistem pengajaran dan pembelajaran di PAUD sudah muali bergeser dari sistem klasikal (satu kegiatan untuk seluruh siswa) ke model TFP (term, fac, and principle)/model pembelajaran sentral yang memberikan pijakan (scaffolding) kepada anak untuk mebangun konsep, aturan, dan ide-ide.

Realitas yang terjadi saat ini masih ada dibeberapa masyarakat pedesaan yang belum memanfaatkan kesempatannya untuk membeikan pendidikan usia dini terhadap anak-anak mereka, hal ini ada beberapa faktor yang mempengaruhi seperti: (1) faktor ekonomi, karena dari segi biaya cukup lumayan mahalnya kalau dibanding dengan biaya di sekolah dasar bahkan gratis, (2) di daerah pedesaan bahkan pegunungan jarak tempuh tidak terjangkau, (3) kesibukan orang tua untuk mencari nafkah. Hal-hal inilah yang terjadi saat ini, untuk kedepannya pemerintah agar memeratakan pendidika usia dini sampai kepelosok-pelosok melalui biaya APBN. Selama ini pendidikan anak usia dini (PAUD) bahkan TK lebih banyak dibangun oleh perseorangan dalam bentuk yayasan.

\section{PEMBAHASAN}

Pendekatan pembelajaran anak usia dini sebagai ajang utama dalam penanamkan pengetahuan terhadap anak Indonesia yang berumur 4-5 tahun dilakukan berbagai setrategi sebagai sebuah ketrampilan dalam mengartur pembelajaran yang sesuai, agar mencapai hasil maksimal yang merupakan harapan masyarakat. Sehingga strategi pembelajaran dapat diartikan suatu alat interaksi di dalam proses pembelajaran, dengan demikian kegiatan pembelajaran berlangsung baik sehingga tujuan yang sudah ditetapkan dengan baik pula. Ada strategi-trategi khusus yang dapat dilakukan guna memenuhi kebutuhan-kebutuhan anak didik serta penyempurnaan pembelajaran yang dilakuakn oleh guru.

Tujuan dari penggunaan strategi pembelajaran di PAUD adalah, pertama untuk mengatifkan anak belajar dengan kondisi yang menyenangkan tanpa adanya tekanan-tekanan secara mental ataupun emisional; kedua memperoleh 
perubahan perilaku anak didik sebagai hasil belajar yang sudah diorganisasikan; ketiga membuat lingkungan belajar yang merangsang dan menantang anak serta mengembangkan seluruh aspek perkembangan baik afeksi, konitif, bahasa, motorik maupun sosial emosienal. Dalam penyelenggaraan bermain dengan strategi bagi anak didik maka dibutuhkan ketrampilan dan strategi yang dapat membantu guru untuk mengajar di PAUD. Beberapa strategi yang dapat dilakukan sebagai berikut.

\section{A. Strategi Pembelajaran dengan Pendekatan Area-area Kegiatan.}

Area kegiatan merupakan pusatpusat belajar yang diberi tanda di dalam kelas, diisi dengan berbagai jenis kegiatan belajar dan alat-alat berdasarkan pada program kemampuan dasar tiap kelas, serta pada tema dan subtema yang sedang dalam pembahasan. Area-area kegiatan ini didesain untuk mengajarkan anak sebuah konsep-konsep yang spesifik. Konsep-konsep tersebut dapat diciptakan sendiri oleh guru, guru bersama anakanak atau anak-anak itu sendiri. Area-area kegiatan ini memberikan kesempatan pada anak-anak memanipulasi bendabenda, melakukan permainan drama, serta berkomunikasi anak satu dengananak yang lainnya melalui percakapan dan pembuatan perencanaan bermaian dan belajar sesuai dengan kemampuan masing-masing anak didik.

Rencana bermain merupakan strategi utama dengan program belajar anak di PAUD. Setiap hari anak-anak membuat rencana apa yang akan mereka mainkan pada waktu bermain di areaarea kegiatan nanti. Melalui pengalaman merencanakan kegitan-kegitan hari ini, anak-anak akan belajar mengeluarkan gagasan-gagasan yang mereka pikirkan dan mendapatkan penemuan-penemuan.

Mereka mengembangkan perasaan, menguasaai tindakan mereka, serta belajar memercayai sumber pokok mereka

Dasar pemikiran dalam pendekatan pembelajaran dengan strategi area-area maka kegiatan bertolak dari tiga alasan sebagai berikut.

1) Area kegiatan memberikan serangkaian pengalaman yang telah diatur dan tersususn secar saksama, yang menantang pengembangan komunikasi serta ketrampilanketrampiulan sosial, kemandirian, kemampuan membuat pilihanpilihan dan nilai-nilai seperti menghargai, menolong, serta memahami orang lain.

2) Area-area kegiatan menjawab tuntunan program ank usia dini yang mengakomodasi tingkat-tingkat perkembangan serta kebutuhan anak dengan cara memberikan berbagi pengalaman sehingga anakanak dapat berkembang sesuai dengan kepercayaannya masingmasing.

3) Area kegiatan menekankan pada keingintahuan anak yang alamiah, hasrat untuk belajar serta gaya belajar yang aktif dengan menyediakan kegiatan-kegiatan berekspirimen, instansi serta penemuan. 
Langkah-langkah dalam mengimplementasikan pendekatan area-area kegiatan seperti berikut.

1) Menetapkan secara realitas jumalah area kegiatan serta banyaknya peralatan yang dapat dapat diatur dalam area kegiatan.

2) Petunjuk untuk bepergian dari satu sentra kesentra lainnya, memasuki danmeinggalkan tiap area kegiatan serta penggunaan alat-alat di dalam area-area kegiatan hendaknya secar eksplisit dijelaskan sebelum anakanak menggunakan tempat-tempat tersebut.

3) Guru juga menyiapkan kartu-kartu yang bertulis nama area kegiatan, warna dan simbol arean kegiatan, dan lain-lainnya.

Alat-alat/perlengkapan dalam area kegiatan perlu mendapatkan perhatian khusus. Berikut saran yang dapat membantu guru antara lain;

1) Pilih alat-alat yang digunakan untuk sehari-hari sesuai dengan perencanaan guru.

2) Tempatkan alat-alat diatas rakrak rendah dekat menja area kegiatan di mana alat-alat tersebut akan digunakan, namun bisa juag menempatkan beberapa alat di meja-menja kegiatan yang dilakukan sebelum anak-anak memasuki pusat-pusat kegiatan.

3) Simpanlah alat-alat dalam wadahwadah menurut jenisnya atau menurut set (kumpulannya).

4) Alat-alat perlu digilir aau ditukartukar secara berkala.
5) Berikan kesempatan kepada anak-anak untuk menggunakan alat-alat maupun mainan yang disiapkan selama kegiatan bermain bebas di area-area kegiatan yang berlangsungantra 1 sampai 2 jam.

Macam area-area kegiatan di dalam kelas antarlain:

1) Area seni.

2) Area balok.

3) Area penemuan sains.

4) Area bermain dramatisasi.

5) Area bahasa.

6) Ara meja permainan.

Disampung area yang telah disiapkan di dalam kelas, ada pula area yang disiapkan di luar kelas atau di luar ruangan. Area inilah memberikan kesempatan kepada anak untuk merencakan serta mengatur pikiran mereka sendiri. Area yang di sediakan diluar ruangan berupa bak pasir, selain itu juga disediakan alat permainan edukatif, luar lainnya seperti tangga majemuk, pemerosotan, ayunan, dan panjat tali.

Pada intinya, strategi pembelajaran dengan pendekatan area-area kegiatan terdiri dari area pembukaan, kegiatan inti, dan kegiatan penutup.

\section{B. Strategi Pembelajaran dengan Pendekatan Sentra dan Waktu Lingkaran}

Sentra dapat diartikan sebagai suatu wadah yang disiapkan oleh guru untuk kegiatan bermain anak, dimana dalam kegiatan tersebut guru dapat mengalirkan materi pembelajaran yang sebelumnya 
telah direncakan dan disusun dalam bentuk lessen-plan.

Kegiatan yang dibuat oleh guru saling berkaitan dan saling mendukung satu dengan yang lainya, sehingga dapat mencapai tujuan belajar harian. Dari semua sentra yang disiapkan oleh guru setiap harinya memilki tujuan yang sama. Dan setiap sentra memilki center point yang mengacu pada tujuan pemeblajaran yang lebih direncanakan oleh tim guru. Satu kelompok akan mengabiskan waktu bermain mereka dalam satu sentra setiap harinya.

Pada kegiatan-kegiatan di sentra dilaksanakan dengan menggunakan tema secara serempak untuk tiap sentra dan dijalankan dengan jangka waktu tertentu. Kegiatan sentra dilakukan dengan memperhatikan tahapan-tahapan kegiatan, dimulai saat pagi hari saat kegiatan penyambutan kedatangan anakanak ke sekolah sampai pada kegiatankegiatan yang telah disipakan oleh guru hingga akhirnya anak kembali kepada keluarga saat penjemputan. Kegiatankegiatn tersebut akan menjadi pedoman guru untuk mengukur perkembangan anak dengan menjadikannya dalam bentuk data-data. Selain itu sentra anakanak belajar disiplin melalui kesempatan aturan-aturan antara anak dengan gurunya, namun penerapan disiplin tidak bermuara pada hukuman. Untuk itu harus mempunyai sumber-sumber yang kuat terhadap makna aturan yang diberikan secara stimulus dan secara kontinu, hingga akhirnya anak memahami apa yang akan mereka lakukan untuk menjalankan kesepakatan dalam setiap kegiatan.
Sentra dapat membantu anak untuk mendapatkan refrensi disiplin secara langsung, sehingga anak akan mengerti untuk apa dan mengapa aturan itu dibuat. Contoh, pada saat anak mengambil balok, anak-anak akan dapat memahmi mengapa balok hanya diambil secukupnya, hanya dua balok saja karena ada dua tangan yang dapat memegangnya. Jika balok diambil lebih banyak dari kemampuan anak untuk memegangnya, maka balok yang diambil akan bisa lepas dari tangannya akan menimbulkan bahaya bagi anggota tubuh yang tertimpa balok yang jatuh tersebut. Contoh yang lain, di dalam ruangan anak-anak tidak bermain bola kaki. Jika bermain bola kaki di dalam ruangan maka akan menimbulkan kekacauan, disamping itu juga akan kena benda-benda yang ada di dalam ruangan menjadi berantakan. Anak akan diajak menemukan pengertian kenapa bermain bola kaki harus di lapangan, bukan di dalam ruangan.

Elemen-elemen penting yang menjadi sifat pembleajaran di sentra adalah pembelajaran non-direct teaching atau tidak mengurui anak. Dan pada pendekatan ini guru tidak melarang, tidak menyuruh, dan tidak memarahi anak. Semua yang dilakukan oleh anak bersumber dari anak itu sendiri, sedangkan guru hanya berperan sebagai motivator dan fasilotator. Untuk dapat menemukan anak sehingga mereka mampu menemukan dan memiliki ide sendiri, guru menyediakan bahan-bahan dan alat-alat main yang sesuai dengan kebutuhan dan tingkat perkembangan anak. Setiap anak dikelompokkan sesuai 
dengan usia kronologisnya, dan bahanbahan serta alat mainan yang disiapkan oleh guru disesuaikan dengan tahap perkembangan biologisnya. Hal ini dilakukan untuk mendukung kemampuan anak di dalam melakukan pekerjaan (bermain). Jika anak diberikan mainan yang kerumitannya lebih tinggi dari tahap perkembangannya, maka anak-anak akan merasa putus asa bila tidak dapat menyelesaikannya. Jika anak diberikan tingkat kerumitan mainnya lebih rendah dari tahap perkembangannya, maka anak akan cepat merasa bosan dan akhirnya bisa tidak focus atau bahkan mengganggu teman-teman sebagai penyaluran ketidak puasannya. Hal ini menjadi perhatian oleh guru, sehingga dia dapat membaca anak yang dihadapinya sedang berada pada tahap perkembangan yang bagaimana.

Penyediaan bahan-bahan dan alat main yang sesuai dengan tahap perkembangan anak akan mendukung anak untuk dapat menemukan sendiri pengetahuannya melalui pengalamanpengalaman main yang menyenangkan. Apa yang ditemulkan oleh anak dengan sendirinya akan menjadi pondasi yang kuat untuk anak, sehingga dapat membangun proses berpikirnya. Guru sebaiknya membantu anak untuk semakin mencintai dan semakin pandai belajar, sehingga dapat belajar pada saat membutuhkan.

Sentra sendiri bertujuan untuk mengorganisasikan informasi dan pengetahuan yang masuk ke otak anak. Jika informasi atau pengetahuan yang diterima oleh anak secara rapi dan teratur, maka akan terasa manfaatnya dikemudian hari. Manfaat tersebut tidak hanya dirasakan anak pada saat menyelesaikan ujian sekolah, tetapi juga ketika anak menghadapi persoalan dalam hidupnya dan dapat menyelesaikannya sendiri. Dengan kata lain, dengan sentra anak belajar sistimatika befikir sejak dini.

Dalam kegiatan sentra, anak dirangsang untuk anak aktif dalam kegiatan bermain, anak menjadi pusat pembelajaran dan guru lebih berperan sebagai motivator dan fasilitator yang memberikan pijakan-pijakan pendidikan (scaffolding). Pijakan-pijakan tersebut membuat anak menjadi kuat dan kukuh terhadap kepastian dari apa yang telah mereka temukan saat bermain. Dalam pijakan-pijakan anak akan mendapat pengetahuan yang lebih mendalam, kosakata-kosakata baru dan ide-ide yang dapat mereka tuangkan kedalam kegiatan bermainnya.

Sentra menjadi tempat yang menyenangkan bagi anak, anak bermain tanpa tekanan dari guru dan lingkungan, anak menjadi kreatif dan menemukan halhal baru yang menjadi milikinya sendiri. Anak-anak merasa nyaman karena guru selalu memberikan dukungan yang positif, anak mendapatkan penghargaan atas setiap kerja yang mereka lakukan. Sehingga hal ini menimbulkan energy postif dalam diri anak dan membuat seluruh potensi kecerdasaannya terbangun dan membuat mereka tumbuh menjadi anak-anak kreatif dan bersyukur. Kegiatan main di sentra pada anak usia dini dikelompokkan dalam tiga jenis main, yaitu main sensorimotor, main peran, dan main pembangunan. Untuk 
mendukung proses itu, perlu desain ruangan yang spesifik sesuai karakteristik masing-masing sentra. Ruang antara sentra yang satu dengan sentra yang lainnya hanya dibatasi dengan rak mainan dan loker-loker, sehingga memudahkan anak untuk bereksplorasi secara bebes menggunakan seluruh indranya, tanpa menggangu aktivitas masing-maisng sentra, juga memudahkan guru untuk saling berkomunikasi dan berinteraksi dalam mendukung proses belajar mengajar.

Dalam satu hari anak menghabiskan waktunya bermain pada satu sentra, dan ke esokkan harinya anak akan pindah kesentra yang lainnya. Setiap sentra mempunyai tema dan TFP yang sama, sehingga saat anak memasuki sentra akan mendapatkan pemberian rangsangan pendidikan yang sama, artinya anak akan mendapatkan pembelajaran yang dialirkan oleh gurunya adalah sama untuk setiap sentra yang mereka lalui. Hal ini sesuai dengan prinsip pembelajaran anak usia dini yang berulang-ulang. Walaupun bentuk kegiatan atau mainan yang mereka jumpai pada sentra adalah berbedabeda, namun substansi ilmu yang anak dapatkan adalah sama. Cara seperti inilah membuat anak semakin kuat pada setiap materi yang diberikan oleh guru pada hari pertama mendapatkan materi dari guru pada salah satu sentra, esok harinya anak akan mendapatkan materi yang sama dari sentra dan guru yang lainya.

Ada tujuh sentra yang dikembangkan oleh penemuan Indonesia yaitu; (1) sentra persiapan, (2) sentra balok, (3) sentra main peran besar, (4) sentra main peran kecil, (5) sentra bahan alam, (6) sentra seni, dan (7) sentra imtaq (iman dan taqua).

\section{Metode Pembelajaran AUD}

Belajar adalah proses perubahan perilaku berdasarkan pengalaman dan latihan. Prinsip-prinsip belajar merupakan suatu ketentuan yang harus dilakukan anak ketika belajar. Anak merupakan pembelajaran yang aktif. Saat bergerak, anak mencari stimulus yang dapat meningkatkan kesempatan untuk belajar. Metode pembelajaran adalah pola umum perbuatan guru dan murid dalam mewujudkan kegiatan belajar mengajar. Metode pembelajaran adalah segala usaha guru untuk menerapkan berbagai metode pembelajaran dalam mencapai tujuan yang diharapkan. Dengan demikian, metode pembelajaran menekankan kepada bagaimana aktivitas guru mengajar dan aktivitas anak belajar. Anak mengunakan seluruh tubuhnya sebagai alat untuk belajar, dan secara energy mencari cara untuk menghasilkan potensi maksimum. Tugas guru adalah bagaimana menyediakn lingkungan yang memungkinkan anak memperoleh pengalaman fisik, sosial, dan mampu merefleksinya. Anak belajar dengan gaya yang berbeda. Ada tiga tipe gaya belajar yaitu tipe visual, tipe auditorial, dan tipe kinestik. Anak belajar melalui bermain, dengan bermain anak dapat memahami, menciptakan, memanipulasi simbolsimbol, dan mentransformasikan objekobjek tersebut. Untuk belajar dalam bermain guru harus mampu memilih metode pembelajaran yang tepat pada pendidikan usia dini (PAUD). 
Metode pembelajaran PAUD terdiri dari beberapa metode yang dapat digunakan guru antara lain:

\section{Metode Pembelajaran Bermain}

Dworetzky memberikan batasan bermain, setidaknya ada lima kriteria dalam bermaian yaitu; (1) motivasi intrinsik yaitu motivasi bermain muncul dari dalam diri anak itu sendiri, bukan karena ada tuntutan dari luar dirinya; (2) pengaruh positif yaitu kegiatan bermain merupakan tingkah laku yang menyenangkan atau mengembirakan; (3) bukan dikerjakan sambi lalu yaitu kegiatan main merupakan kegiatan utama anak dan lebih bersifat pura-pura; (4) cara atau tujuan yaitu cara bermain lebih diutamakan dari pada tujuan bermain.; (5) kelenturan bermaian yaitu kelenturan ditunjukkan baik dalam bentuk maupun dalam hubungan serta belaku dalam setiap situasi.

Melalui kegiatan bermain diharapkan seluruh potensi kecerdasan anak dapat dikembangkan, selain itu kegiatan bermain bagi anak sangat mempengaruhi perkembangannya baik melalui perkembangan fisik, dorongan komunikasi, penyaluran bagi emosional yang terpendam, penyaluran bagi keinginan dan kebutuhan, sumber belajar, rangsangan bagi kreativitas, perkembangan wawasan diri, belajar masyarakat, standar moral, dan perkembangan cirri kepribadian yang diinginkan.

\section{Metode Penbelajaran Melalui Bercerita}

Berceritra adalah cara bertutur dan menyampaikan ceritra atau memberikan penjelasan secara lisan. Berceritra juga merupakan cara untuk menyampaikan nilai-nilai yang berlalu dimasyarakat. Isi ceritra diupayakan berkaitan dengan; a) dunia kehidupan anak yang penuh suka cita, yang menuntut isi ceritra memiliki unsur yang dapat memberikan perasaan genbira, lucu, menarik, dan mengasyikkan bagi anak, b) disesuaikan dengan minat anak yang biasanya berkenan dengan binatang, tanaman, kendaraan dan lainlainya, c) tingkat usia, kebutuhan dan kemampuan anak menangkap isi ceritra berbeda-beda, d) membuka kesempatan bagi anak untuk bertanya dan menanggapi setelah guru selesai berceritra.

\section{Metode Pembelajaran Melalui Bernyanyi \\ Hoing (dalam Zukhairina,} 2014:112) menyatakan bahwa bernyanyi memiliki banyak manfaat untuk praktik pendidikan anak dan pengembangan pribadi anak secara luas, karena; (1) bernyanyi bersifat menyenangkan; (2) benyanyi dapat dipakai untuuk mengatsi kecemasan; (3) bernyanyi merupakan media untuk mengekspresikan perasaan; (4) bernyanyi dapt membantu daya ingatan anak; (5) bernyanyi dapat mengembangakn ketrampilan berpikir, dan (6) bernyanyi dapat meningkatkan keeratan dalam kelompok. 


\section{Metode Pembelajaran Terpadu}

Pembelajarn terpadu memilki karakteristik antara lain: (1) dilakukan melalui kegiatan pengalaman langsung; (2) sesuai dengan kebutuhan dan minat anak; (3) memberikan kesempatan kepada anak untuk menggunakan semua pemikirannya; (4) menggunakan bermain sebagai wahana belajar; (5) menghargai perbedaan individu,dan (5) melibatkan orang tua dan keluarga untuk mengoptimalkan pembelajaran.

Manfaat penggunaan metode pembelajaran terpadu, yaitu; (1) meningkatkan perkembangan konsep anak; (2) memungkinkan anak untuk dapat beroksplorasi pengetahuan melalui bermain dengan berbagai macam kegiatan; (3) membantu guru dan praktisi lainnya untuk dapat mengmbangkan kemampuan profesionalnya; (4) dapat dilaksanakan pada jenjang program yang berbeda dalam tingkat usia, dan untuk anak berkebutuhan khusus. Kemudian prosedur pelaksanaan pembelajaran terpadu terdiri dari; (1) memilih tema; (2) penjabaran tema; ( 3) perncanaan; (4) pelaksanaan; dan( 5) penilaian.

\section{Metode Pembalajaran Demontrasi}

Hampir pada setiap kegiatan main akan terjadi pengalaman-pengalaman baru yang menimbulkan kegiatan belajar pada anak. Pengalamanpengalaman yang dikenal dengan pengalaman belajar tersebut diperoleh anak melalui penglihatan, pendengaran, dan peniruan. Perolehan pengalaman belajar yang dirancang secara khusus untuk menunjukkan, mengerjakan, dan menjelaskan suatu proses dari suatu peristiwa yang sedang dilakukan merupakan salah satu metode bermain yang disebut demontrasi.

Beberapa bentuk kegiatan yang sesuai dengan metode demontarsi dalamrangka memberikan pengalaman belajar antara lain: (1) kegiatan yang bertujuan melatih koodinasi mata dan jari-jemari, seperti memegang dan menggunakan alat tulis, membangun dengan alat, dan bahan main yang bersifat konstruksi, mengikat tali sepatu, memasamg kancing baju, memakai kaos kaki, serta membuka dan menutup alat makan minum; (2) kegiatan bertujuan melatih koordinasi tubuh atau gerakangerakan dasar, seperti gerakan merayap, meranggak, berjalan pada balok titian, menagkap dan melambungkan bola, dan lain-lainnya.

\section{Metode Pembelajaran Pemberian Tugas \\ Tugas atau pekerjaan yang diberikan} kepada anak untuk melaksanakan tugas berdasarkan petunjuk (aturan) yang telah diberikan oleh guru sebelumnya, sehingga anak dapat mengalami secara nyata dan melaksanakan pekerjaan dari awal sampai tuntas. Tugas atau pekerjaan yang diberikan dapat dikerjakan secara berkelompok atau individual.

\section{Metode Pembelajaran Bercakap- cakap (berdialog)}

Bercakap-cakan ini berkembangn menjadi suatu dialog bahan akan bersifat diskusi karena dapat melibatkan 
dua orang atau lebih. Manfaat nyata dari bercakap-cakap antaralain; (1) meningkatkan kebranian anak untuk berbicara; (2) melatih kemampuan anak untuk mendengarkanpembicaraan dan menagkap pesan dari orang lain;(3) membangu konsep diri yang positip; (4) memperluas pengetahuan dan meningkatkan pembendaharaan kosakata yang dimiliki anak; dan (5) meningkatkan kebranian anak untuk mengadakan hubungan dengan orang lain seperti gurudan teman-temannya.

\section{Model Pembelajaran AUD}

Kurikulum PAUD bertujuan untuk mengembangkan seluruh potensi anak (the whole child) agar kelak dapat berfungsi sebagai manusia yang utuh sesuai dengan kultur dan falsafah bangsa. Dari sudut efistemology, kajian tentang metodelogi pembelajaran anak usia dini telah dikembangkan dengan acuan filosofis, pendekatan, dan metode yang beraneka ragam, termasuk dalam kajian tentang model kurikulum untuk anak usia dini. Sesuai dengan landasan filsafatnya maka pengembangan kurikulum anak usia dini secara garis besarnya dikelompokkan kedalam tiga model yaitu: (1) model pematangan (maturations models) yang didasari oleh teori Gessel, Freud, dan Erikson, menurut pandangan ini anak memiliki blueprint (cetak biru) pada tingkah laku tertentu. Perubahan tingkah laku terjadi sebagai hasil kematangan psikologis (kesiapan) dan stuasi lingkungan yang mengandung tingkah laku tertentu (tugas-tugas perkembangan). (2) model aliran tingkah laku lingkungan didasari teori Skiner dan Bandura. Menurut model ini, anak-anak dilahirkan bagai suatu batu tulis yang kosong (blank slate), tingkah laku anak yang pasif dibentuk oleh kondisi lingkungan. Perubahan tingkah laku terjadi sebagai hasil dari penguatan suatu peristiwa yang terencana dan tidak terencana. (3) model interaksi yang didasari oleh teori Vigotsky, model ini beranggapan bahwa perkembangan anak merupakan hasil perpaduan antara heriditas dan pengaruh lingkungan. Perkembangan akan terjadi pada seseorang ketika orang melakukan pengorganisasian diri yang dicapai pada tahap optimal oleh peristiwa yang dieksperimentasikan.

\section{SIMPULAN}

Kebijakan pemerintah secara nasional untuk menyusun berbagai program yang terkait dengan pengasuhan pendidikan, dan pengembangan anak usia dini, sebagai wujud nyata komitmen pemerintah adalah beberapa kebijakan dasar yang temuat dalam dokumen berupa "Program Nasional Bagi Anak Indonesia (PNBAI)" sampai 2015 yang isinya antara lain: (1) mewujudkan anak yang sehat, tumbuh dan berkembang secara optimal melalui pemberdayaan masyarakat, (2) peningkatan kerja sama lintas sektoral, perbaikan lingkungan, peningkatan kualitas kesehatan, peningkatan sumber daya manusia, serta pengembangan ilmu pengetahuan, (3) mewujudkan perlindungan dan partisipasi aktif anak melalui perbaikan mutu pranata sosial anak. 
Pendekatan pembelajaran anak usia dini sebagai ajang utama dalam penanamkan pengetahuan terhadap anak Indonesia yang berumur 4-5 tahun dilakukan berbagai setrategi sebagai sebuah ketrampilan dalam mengartur pembelajaran yang sesuai, agar mencapai hasil maksimal yang merupakan harapan masyarakat. Sehingga strategi pembelajaran dapat diartikan suatu alat interaksi di dalam proses pembelajaran, dengan demikian kegiatan pembelajaran berlangsung baik sehingga tujuan yang sudah ditetapkan dengan baik pula. Ada strategi-trategi khusus yang dapat dilakukan guna memenuhi kebutuhan-kebutuhan anak didik serta penyempurnaan pembelajaran yang dilakukan oleh guru.

Tujuan dari penggunaan strategi pembelajaran di PAUD adalah, pertama untuk mengatifkan anak belajar dengan kondisi yang menyenangkan tanpa adanya tekanan-tekanan secara mental ataupun emisional; kedua memperoleh perubahan perilaku anak didik sebagai hasil belajar yang sudah diorganisasikan; ketiga membuat lingkungan belajar yang merangsang dan menantang anak serta mengembangkan seluruh aspek perkembangan baik afeksi, konitif, bahasa, motorik maupun sosial emosienal yang ada pada anak.

Untuk mencerdasakan anak bangsa yang diawali dengan pendidikan anak usia dini merupakan awal yang akan menuju pendidikan formal, sehingga pendidikan awal sampai di perguruan tinggi tidak ada diskriminasi terhadap orang-orang yang berkelas. Pendidikan usia dini sampai kependidikan dasar merupakan pondasi yang sangat perlu memperoleh perhatian oleh kedua orang tua maupun lingkungannya. Pendidikan pada anak usia dini dimana guru lebih menekankan pada pola bermain. Anak bermain dengan menggunakan mainan yang konkrit (nyata), dengan mainan tersebut anakanak belajar banyak hal seperti: warna warni, ukuran, bentuk, besar kecil, berat ringan, kasar halus, dan selain itu anak akan belajar mengelompokkan benda, cirri-ciri benda, dan sifat-sifat benda. Kemampuan anak untuk belajar tersebut akan terus terbangun baik saat anak anakanak bemain maupun saat mereka beresberes setelah mereka bermain.

Anak bermain untuk memperoleh sesuatu dengan cara berekplorasi atau menemukan sesuatu dan berekspirimen atau dengan pengamatan sendiri tentang dunia di sekitarnya dalam rangka membangun pengetahuan diri sendiri (self knowledge). Untuk dapat mendukung anak berekplorasi dengan mainnya guru perlu memerhatikan densitas (density) dan itensitas (intensity) main.

\section{DAFTAR PUSTAKA}

Anita Yus. 2011. Mode Pendidikan Anak Usia Dini. Jakarta: Kencana Media Group.

Ajeng Yusriana. 2012. Kiat-kiat Menjadi Guru PAUD yang Disukai Anakanak. Yogyakarta: DIVA Pres.

Arief Sadirman, S., dkk. 2010. Media Pendidikan. Jakarta: Rajawali Pres. 
Badru Zaman. 2010. Media Pembelajaran Anak Usia Dini. Bandung: UPI.

Benhartin Panggabean HD. 2010. Musik dan Lagu Anak Usia Dini. Bandung: UPI.

Conny Semiawan. 2005. Perspektif Pendidikan Anak Berbakat. Jakarta: Grasindo.

Departemen Pendidikan Nasional. 2008. Kamus Besar Bahasa Indonesia (KBBI). Edisi IV. Jakarta: Gramedia.

Direktorat Pendidikan Anak Usia Dini. 2002. Acuan Menuju Pembelajaran pada Pendidikan Anak Usia Dini. Jakarta: Departemen Pendidikan Nasional.
Fasli Jalaj. 2010. Arah Kebijakan Nasional Pendidikan Anak Usia Dini (Jalur Pendidikan Nonformal), disampaikan pada Semiloka Nasional PAUD. Jakarta.

Gomma. Abla Bassat. 2011. Membentuk Kepribadian Anak Sejak Dini (terj. Muhammad Zaky Abdullah. Solo: Samudra

Undang-Undang No. 20 Tahun 2003 tentang Sistem Pendidikan Nasional. Jakarta.

Zukhairina,dkk. 2014. Orientasi Baru Pendidikan Anak Usia Dini Teori dan Aplikasi. Jakarta: Kencana Prenadamedia Group. 